Irwan, A.W. • T. Nurmala

\title{
Pengaruh pupuk hayati dan pengapuran terhadap produktivitas kedelai di tanah Inceptisol Jatinangor
}

\section{Influence of biofertilizer and lime on soybean productivity in Inceptisols Jatinangor}

Diterima : 27 Maret 2018/Disetujui : 1 Agustus 2018 / Dipublikasikan : 7 Agustus 2018

CDepartment of Crop Science, Padjadjaran University

\begin{abstract}
Soybean is a food plant with high vegetable protein content, is always lack of demand. Its yield can be improved by biofertilizer and lime application. This research was conducted at Experimental Field of Agricultural Faculty of Padjadjaran University, Jatinangor, Sumedang, on Inceptisols, from March 2017 to June 2017. It used Randomized Block Design, nine treatments and three replications, as follows: without biological fertilizer and without liming (control); biological fertilizer 5 liters / ha + without liming; biological fertilizer 8 liters / ha + without liming; without biological fertilizer + liming 140 $\mathrm{kg} / \mathrm{ha}$; biological fertilizer 5 liters / ha + liming $140 \mathrm{~kg} / \mathrm{ha}$; biological fertilizer 8 liters / ha + liming $140 \mathrm{~kg}$ / ha; without biological fertilizer + liming $200 \mathrm{~kg}$ / ha; biological fertilizer 5 liters / ha + liming $200 \mathrm{~kg} / \mathrm{ha}$; and biological fertilizer 8 liters / ha + liming $200 \mathrm{~kg} / \mathrm{ha}$. The results showed that there were no significant effect on the number of pods, the number of seeds, the number of flowers, the dry weight of the plant, the effective root nodule, leaf area index (ILD), yield, harvest index, and 100 grain weight, but there were significant effect on plant height and number of productive branches. The best yield reached $36.86 \mathrm{~g} /$ plant or about 1.1 tons / ha.
\end{abstract}

Key words : Soybean $\cdot$ Liming, Biological fertilizer - Inceptisols.

\footnotetext{
Dikomunikasikan oleh Ruminta

Irwan, A.W. ${ }^{1} \cdot$ T. Nurmala ${ }^{2}$

1 Staf Pengajar Fakultas Pertanian Universitas Padjadjaran

2 Guru Besar Fakultas Pertanian Universitas Padjadjaran

Korespondensi: a.wawan.irwan@unpad.ac.id
}

Sari. Kedelai merupakan tanaman pangan dengan kandungan protein tinggi sebagai bahan baku utama berbagai makanan, sehingga kebutuhan kedelai di Indonesia selalu tinggi. Hasil kedelai dapat ditingkatkan melalui aplikasi pupuk hayati dan pengapuran. Penelitian ini dilaksanakan di Kebun Percobaan Fakultas Pertanian Universitas Padjadjaran, Jatinangor, Sumedang pada ordo tanah Inseptisol. Penelitian dilakukan dari Maret 2017 sampai Juni 2017. Rancangan percobaannya adalah Rancangan Acak Kelompok, terdiri dari sembilan perlakuan, yaitu tanpa pupuk hayati dan tanpa pengapuran (kontrol); pupuk hayati 5 liter/ha + tanpa pengapuran; pupuk hayati 8 liter/ha + tanpa pengapuran; tanpa pupuk hayati + pengapuran $140 \mathrm{~kg} / \mathrm{ha}$; pupuk hayati 5 liter/ha + pengapuran $140 \mathrm{~kg} / \mathrm{ha}$; pupuk hayati 8 liter/ha + pengapuran $140 \mathrm{~kg} / \mathrm{ha}$; tanpa pupuk hayati + pengapuran $200 \mathrm{~kg} / \mathrm{ha}$; pupuk hayati 5 liter/ha + pengapuran $200 \mathrm{~kg} / \mathrm{ha}$; dan pupuk hayati 8 liter/ha + pengapuran 200 $\mathrm{kg} / \mathrm{ha}$. Semua perlakuan diulang 3 kali. Hasil percobaannya yaitu aplikasi pupuk hayati dan pengapuran tidak menunjukkan berpengaruh nyata terhadap jumlah polong, jumlah biji, jumlah bunga, bobot kering tanaman, bintil akar efektif, Indeks Luas Daun (ILD), bobot biji, Indeks Panen dan bobot 100 butir, namun berpengaruh nyata pada pengamatan tinggi tanaman serta jumlah cabang produktif. Hasil panen tertinggi mencapai $36,86 \mathrm{~g} /$ tanaman atau sekitar 1,1 ton/ha.

Kata kunci : Kedelai, Pengapuran, Pupuk hayati - Inceptisols. 


\section{Pendahuluan}

Kedelai (Glycine max (L.) Merill) merupakan salah satu tanaman pangan yang mengandung protein nabati yang cukup tinggi. Kedelai merupakan salah satu komoditas pangan terpenting ketiga setelah padi dan jagung (Swastika, dkk., 1997) dan menduduki posisi ketiga sebagai tanaman palawija setelah jagung dan ubi kayu (Silitonga, dkk 2013). Kedelai telah menjadi konsumsi harian bagi seluruh masyarakat Indonesia dari setiap kalangan karena rasanya yang enak. Kedelai sebagai bahan baku utama makanan dan minuman seperti tahu, tempe, kecap hingga susu, sehingga kedelai di Indonesia selalu mengalami peningkatan permintaan khususnya para pihak industri yang menggunakan kedelai.

Produksi kedelai di Indonesia ini masih rendah dan belum bisa memenuhi seluruh kebutuhan akan kedelai di dalam negeri, produktivitas kedelai rata-rata Indonesia masih rendah (1,57 ton/ha) dibandingkan dengan produktivitas kedelai di Amerika ( $>3$ ton/ha); bila dilihat dari provintsi penghasil kedelai tertinggi berada di Sulawesi Tengah $(1,87$ ton/ha); produksi kedelai di Indonesia pada tahun 2015 yaitu mencapai 963.099 ton. Produksi kedelai nasional lima tahun terakhir periode 2011-2015 meningkat rata-rata 2,49\% per tahun, Pulau Jawa menyumbang 2,95\% per tahun dan Luar Jawa menyumbang $8,30 \%$ per tahun (Badan Pusat Statistik, 2017). Berdasarkan data BPS tahun 2015 juga diniformasikan, konsumsi tempe rata-rata per orang per tahun di Indonesia sebesar 6,95 kg dan tahun 7,907 kg. Kebutuhan kedelai di Jawa Barat sendiri masih belum terpenuhi, dari total kebutuhan 371.975 ton per tahun, Provinsi Jawa Barat baru memproduksi 98.938 ton. Itu yang menjadi sebab Indonesia masih mengimpor kedelai.

Upaya yang dapat dilakukan untuk meningkatkan produksi kedelai dengan menggunakan varietas unggul dan pemberian pupuk. Pemupukan yang biasa dilakukan petani hanya melalui tanah, sehingga unsur hara yang diberikan diserap oleh akar tanaman, penanaman kedelai di tanah yang subur biasanya jarang menimbulkan masalah, karena bahan-bahan yang sangat dibutuhkan seperti nitrogen telah terkandung di dalamnya. Sebaliknya, jika penanaman dilakukan pada tanah yang kurang subur maka akan mengakibatkan pertumbuhan kedelai yang kurang sempurna atau bahkan tidak diharapkan (Sumardi, 2014). Lahan subur lebih sering digunakan untuk tanaman padi.

Peningkatan produksi juga dapat didu-kung dengan penggunaan mikroba rhizobium, karena dengan rhizobium tersebut akan membentuk bintil akar yang berfungsi untuk pengikatan nitrogen yang akan meningkatkan pertumbuhan vegetatif tanaman. Untuk mengurangi penggunaan pupuk tambahan lainnya maka dapat menggunakan pupuk cair yang telah terkandung rhizobium dan kandungan lainnya atau dapat disebut sebagai pupuk hayati (Novriani, 2011).

Pupuk hayati memiliki prospek yang baik untuk dikembangkan dan saat ini semakin diminati oleh petani karena selain ramah lingkungan, juga dapat meningkatkan produktivitas tanaman. Pupuk hayati merupakan formula pupuk berisi mikroba, baik tunggal maupun beberapa mikroba, dalam satu bahan pembawa dengan fungsi untuk menyediakan unsur hara dan meningkatkan produksi tanaman. Mikroba yang diformulasikan merupakan mikroba yang bermanfaat dan tidak bersifat sebagai patogen (penyebab penyakit) tanaman. Beberapa mikroba yang digunakan sebagai pupuk hayati adalah dari golongan bakteri penambat $\mathrm{N}_{2}$ simbiotik (rhizobia), bakteri penambat $\mathrm{N}_{2}$ nonsimbiotik (antara lain Azotobacter dan Azospirillum), mikroba pelarut P (Bacillus sp., Pseudomonas sp., Streptomyces sp. dan cendawan Trichoderma sp., Aspergillus sp., Penicillium sp.). sehingga baik untuk kesuburan tanah dan pertumbuhan tanaman. (Simanungkalit. 2001)

Sebagian besar lahan di Indonesia, merupakan lahan kering masam, karena kebutuhan dan permintaan kedelai di Indonesia sendiri selalu meningkat, sehingga lahan kering masam terpaksa dijadikan sebagai areal pengembangan kedelai yang harus diperbaiki kesuburannya, antara lain menurunkan tingkat kemasaman tanah pada daerah perakaran yang dapat mencapai kedalaman lebih dari $30 \mathrm{~cm}$. Kapur merupakan amelioran yang umum digunakan untuk menurunkan tingkat kemasaman dan kesuburan tanah. Usaha pertanian pada lahan kering masam akan menghadapi sejumlah permasalahan. Secara kimia, jenis tanah ini umumnya mempunyai $\mathrm{pH}$ rendah $(4,0-5,0)$ yang menyebabkan kandungan $\mathrm{Al}$ terlarut tinggi sehingga dapat meracuni tanaman, tanah miskin unsur hara esensial makro dan mikro seperti $\mathrm{N}, \mathrm{P}, \mathrm{K}, \mathrm{Ca}$, dan $\mathrm{Mg}$, serta bahan organik. Misalnya saja lahan Ultisol dan Inceptisol (Atman, 2006). 
Oleh karena itu diharapkan penggunaan pupuk hayati dan pengapuran dapat meningkatkan produktivitas kedelai pada tanah Inceptisol. Pada penelitian ini didapat kombinasi dosis antara pemberian pupuk hayati dan pengapuran dapat meningkatkan produktivitas tanaman kedelai.

\section{Bahan dan Metode}

Penelitian ini dilaksanakan di Kebun Percobaan Fakultas Pertanian Universitas Padjadjaran, di Ciparanje Kecamatan Jatinangor, Kabupaten Sumedang dengan ketinggian tempat \pm 795 meter di atas permukaan laut ( $\mathrm{m} \mathrm{dpl}$ ), dari bulan Maret 2017 sampai bulan Juni 2017.

Rancangan percobaan yang digunakan adalah Rancangan Acak Kelompok (RAK), dengan perlakuan dosis pupuk hayati dengan dosis kapur. Perlakuan terdiri dari sembilan perlakuan dan tiga ulangan sehingga terdapat 27 satuan percobaan.

Perlakuannya terdiri dari : (A) tanpa pupuk hayati dan tanpa pengapuran (kontrol); (B) pupuk hayati 5 liter/ha + tanpa pengapuran; (C) pupuk hayati 8 liter/ha + tanpa pengapuran; (D) tanpa pupuk hayati + pengapuran $140 \mathrm{~kg} / \mathrm{ha}$; (E) pupuk hayati 5 liter/ha + pengapuran $140 \mathrm{~kg} / \mathrm{ha}$; $(\mathrm{F})$ pupuk hayati 8 liter/ha + pengapuran $140 \mathrm{~kg} / \mathrm{ha}$; (G) tanpa pupuk hayati + pengapuran $200 \mathrm{~kg} / \mathrm{ha}$; (H) pupuk hayati 5 liter/ha + pengapuran 200 $\mathrm{kg} / \mathrm{ha}$ dan (I) pupuk hayati 8 liter/ha + pengapuran $200 \mathrm{~kg} / \mathrm{ha}$.

Analisis data yang digunakan adalah analisis ragam (Uji F) pada taraf $5 \%$, dan uji lanjut yang digunakan adalah Uji jarak berganda Duncan pada taraf nyata 5\%.

Benih kedelai yang digunakan adalah benih varietas unggul, yaitu varietas Anjasmoro. Pada pengolahan lahan, diberikan pengapuran sesuai dengan perlakuan pada 18 petak pada waktu 2 minggu sebelum tanam, lalu pada 1 minggu setelahnya, diberikan pupuk kandang dengan dosis 10 ton/ha. Ukuran lahan pertanaman masing-masing $2 \mathrm{~m} \times 3 \mathrm{~m}$. dengan jarak antar petak $50 \mathrm{~cm}$. Setiap petak terdiri dari 96 tanaman. Kebutuhan benih sebanyak 2 biji/ lubang tanam. Penyulaman dilakukan pada 2 minggu setelah tanam. Pemberian pupuk hayati pada saat tanaman berumur 1 MST (minggu setelah tanam) dan 3 MST. dengan cara disemprot dengan sprayer, sesuai dosis yang telah ditentukan yaitu 5 liter/ha dan 8 liter/ha.
Penyiangan dilakukan dua kali yaitu pada umur tanaman 2 dan 4 minggu setelah tanam dan menjelang fase pembungaan (umur tanaman 7 dan 9 MST). Penyiraman dilakukan setiap hari terutama pada saat turun hujan. Pengendalian hama dan penyekit serta gulma dilakukan dengan menggunakan insektisida Furadan 3G (Karbofuran 3G) $2 \mathrm{~g} /$ lubang tanam pada saat tanam ke dalam lubang tanam dan fungisida Dithane dengan dosis $3 \mathrm{ml} / \mathrm{m}^{2}$ serta herbisida roundup dengan dosis $5 \mathrm{ml} / \mathrm{m}^{2}$.

Panen dilakukan pada saat polong mencapai matang fisiologis yang ditandai dengan $90-95 \%$ polong berwarna kuning kecoklatan (telah kering) dan sebagian besar daun sudah menguning dan telah banyak yang rontok Proses selanjutnya adalah pembersihan biji dengan memisahkan polong dan biji kedelai. Tanaman kedelai yang sudah dipanen kemudian dipisahkan polongnya untuk selanjutnya dijemur di bawah sinar matahari. Biji kedelai selanjutnya dijemur kembali sampai kadar airnya mencapai 9 - 11\%. Biji kemudian ditimbang untuk mengetahui bobot biji per tanaman, dan selanjutnya dihitung hasil panen untuk mengetahui hasil panen benih kedelai.

Pengamatan Penunjang. Pengamatan penunjang dilakukan terhadap faktor diluar perlakuan yang dapat mempengaruhi proses penelitian dan tidak dianalisis secara statistik. Pengamatan penunjang meliputi: analisis tanah awal, dengan mengambil sample tanah untuk kemudian dilakukan pengujian di Laboratorium Departemen Ilmu Tanah Fakultas Pertanian.

Keadaan lingkungan (suhu, curah hujan, dan kelembaban) sejak awal hingga akhir penelitian. Serangan hama, penyakit, dan gulma yang tumbuh serta bobot 100 butir sebelum benih ditanam.

Pengamatan Utama. Komponen Pertumbuhan terdiri dari : tinggi tanaman, jumlah cabang produktif, bobot kering tanaman, jumlah bintil akar efektif dan Indeks Luas Daun (ILD). Pengamatan komponen hasil dan hasil terdiri dari jumlah biji per polong, Jumlah Polong per Tanaman, jumlah biji per tanaman, Bobot 100 Biji , Bobot Biji per Tanaman dan Indeks Panen.

\section{Hasil dan Pembahasan}

\section{Pengamatan Penunjang}

Tanah yang digunakan dalam penelitian ini, dapat diketahui beberapa informasi mengenai 
kandungan kimia tanah serta sifat fisik tanah yaitu tanah yang digunakan termasuk tanah Ordo Inceptisols yang mengandung pasir 26\%, debu $45 \%$ dan Liat $29 \%$.

Berdasarkan hasil analisis, nilai $\mathrm{pH}$ tanah percobaan yaitu 6,03 (agak masam). Pertumbuhan kedelai optimal pada $\mathrm{pH}$ 6,8, namun pada tanah dengan $\mathrm{pH}$ 5,5-6,5 cukup baik untuk kondisi lahan di Indonesia (Ismail dan Effendi 1985). Kedelai cukup responsif terhadap pemberian kapur pada Oxisol dan Inceptisol dengan $\mathrm{pH}$ 4,4-4,7 dan kandungan bahan organik 3,34,6\%, tetapi tidak tanggap pada Ultisol dengan kandungan kandungan bahan organik 5,2\% meskipun $\mathrm{pH}$ tanah 4,2 (Wade et al. 1986). Pada percobaan perlakuan yang diberikan agar $\mathrm{pH}$ tanah menjadi menuju netral yaitu sekitar 6,8 - 7. Kondisi $\mathrm{pH}$ tanah setelah dilakukan pengapuran menjadi tinggi, yaitu untuk pengapuran $140 \mathrm{~kg} / \mathrm{Ha}$ dari $\mathrm{pH}$ 6,03 menjadi 6,58 (agak masam) sementara untuk pengapuran $200 \mathrm{~kg} / \mathrm{Ha}$ dari $\mathrm{pH}$ 6,03 menjadi 6,90 (netral).

Kandungan unsur hara makro N-total 0,16\% termasuk dalam kriteria rendah, sehingga perlu dilakukan penambahan dosis pupuk $\mathrm{N}$ pada tanah yang digunakan dalam penelitian, lalu kandungan $\mathrm{P}_{2} \mathrm{O}_{5}$ yang tersedia pada tanah penelitian adalah $78,27 \%$ termasuk dalam kriteria sangat tinggi dan $\mathrm{K}_{2} \mathrm{O}$ 10,46\% termasuk kriteria rendah sehingga perlu dilakukan penambahan dosis pupuk $\mathrm{K}$ untuk tanah yang digunakan untuk membantu menyediakan unsur hara bagi tanaman. Tanah yang digunakan dalam penelitian ini memiliki nilai $\mathrm{C} / \mathrm{N}$ ratio 8 yang termasuk dalam kriteria rendah, nilai $\mathrm{C} / \mathrm{N}$ ratio tanah ini menunjukan bahwa tingkat dekomposisi bahan organik tergolong rendah.

Pengamatan pada curah hujan, suhu dan kelembaban dilakukan setiap hari selama percobaan menurut hasil pengamatan Stasiun Klimatologi Universitas Padjadjaran pada tahun 2017 diketahui bahwa di daerah Jatinangor mengalami Bulan Kering (BK) selama empat bulan berturut-turut, untuk Bulan Basah (BB) yakni enam bulan berturut-turut dan untuk Bulan Lembab (BL) dua bulan berturut-turut. Tipe curah hujan dengan tipe C3 menurut kriteria Oldeman.

Pada awal percobaan yaitu pada pertengahan bulan Maret dengan rata-rata curah hujan harian dari bulan maret hingga juni yaitu $12,7 \mathrm{~mm} /$ hari , 6,6 mm/hari, 19,8mm/hari dan $1,8 \mathrm{~mm} /$ hari, curah hujan pada bulan maret yaitu $393 \mathrm{~mm} /$ bulan, pada bulan april 199 $\mathrm{mm} /$ bulan, pada bulan mei $66,5 \mathrm{~mm} /$ bulan dan pada bulan juni $54 \mathrm{~mm} /$ bulan. Suhu rata-rata harian selama penelitian berkisar antara 12,2 $28,8^{\circ} \mathrm{C}$ dan sesuai dengan suhu optimum bagi pertumbuhan kedelai yaitu $25-27^{\circ} \mathrm{C}$.

Hama yang menyerang pada tanaman kedelai dalam penelitian adalah ulat jengkal (Chrysodeixis chalcites), ulat grayak (Spodoptera litura) dan belalang hijau (Atractomorpha crenulata). Serangan hama tersebut sudah terlihat sejak tanaman memasuki fase daun ke dua berkembang penuh hingga memasuki waktu panen kedelai, ditandai dengan gejala rusaknya daun dan berlubang akibat gigitan hama tersebut; Gulma yang mengganggu adalah putri malu (Mimosa pudica), jampang pahit (Paspalum conjugatum) dan rumput teki (Cyperus rotundus). Serangan hama, penyakit serta keberadaan gulma pada percobaan ini dapat dikendalikan dengan tingkat serangan kurang dari $5 \%$.

Pengamatan utama dalam penelitian ini terdiri dari tinggi tanaman 4 MST, jumlah cabang produktif, jumlah bunga pada 5 MST dan 7 MST, bobot kering tanaman (berangkasan), jumlah bintil akar efektif dan Indeks Luas Daun (ILD).

Tinggi Tanaman, Bobot Kering Tanaman, jumlah Bintil Akar Efetif dan Jumlah Cabang. Pengamatan tinggi tanaman dilakukan 4 MST. Data pengamatan rata-rata tinggi tanaman dapat dilihat pada Tabel 1. Hasil analisis statistik menunjukan bahwa terdapat pengaruh yang signifikan dibandingkan tanpa perlakuan. Perlakuan pengapuran yang dilakukan berpengaruh terhadap peningkatan $\mathrm{pH}$ tanah penelitian yaitu antara 6 sampai 6,9 sehingga menyebabkan keberadaan unsur hara akan lebih tersedia bagi tanaman namun adanya peningkatan suhu yang relatif tinggi diduga melebihi suhu maksimum tanaman maka menyebabkan penyerapan unsur hara tersebut dari dalam tanah oleh akar terganggu. Hal ini menyebabkan semua perlakuan yang diberikan tidak menunjukkan pengaruh secara nyata terhadap tinggi tanaman. Sesuai pendapat Setyamidjaja, D. (1986) yang mengatakan bahwa tujuan pemberian kapur pada tanah adalah untuk menaikkan derajat keasaman $(\mathrm{pH})$ tanah pada lahan-lahan yang reaksi tanahnya asam menjadi netral sehingga sebagian unsur hara dalam tanah dalam keadaan tersedia bagi tanaman.

Pemberian pupuk hayati pada tanaman kedelai yang berpengaruh pada tinggi tanaman 
belum banyak berpengaruh, hal ini karena pengapuran pada perlakuan yang diberikan belum cukup untuk bereaksi karena terdapat pengaruh dari $\mathrm{Al}$ atau $\mathrm{Fe}$.

Pemberian pupuk hayati pada kedelai dapat meningkatkan tinggi tanaman lebih besar dibandingkan pemberian pupuk standar maupun tanpa pemberian pupuk meskipun tidak nyata meningkatkan secara statistik. Hal ini didukung oleh penelitian Rosmayati (1989), bahwa penggunaan Rhizobium sebagai pupuk hayati, termasuk pupuk nitrogen, serta interaksinya tidak memberikan pengaruh yang nyata terhadap tinggi tanaman, juga pada fase reproduktif. Tanaman pada fase ini, unsur hara yang dibutuhkan lebih banyak unsur P dan K.

Bobot kering tanaman atau berangkasan, Jumlah bintil akar efektif dan jumlah cabang produktif dan Indeks Luas Daun yang diamati pada 6 MST dapat dilihat pada Tabel 1.

Bobot Kering Tanaman. Bobot kering tanaman diamati pada saat tanaman telah dipanen dan dipisahkan dengan polong dan bijinya, lalu batang, akar dan daun yang tersisa ditimbang dengan timbangan analitik untuk mengetahui bobot kering tanaman pada masingmasing perlakuan. Pupuk hayati dan pengapuran tidak menunjukkan pengaruh yang nyata terhadap Bobot kering tanaman (Tabel 1).

Menurut Salisbury dan Ross (1995), $\mathrm{N}_{2}$ bebas yang difiksasi secara hayati akan membantu peningkatan fotosintesis, kemudian fotosintat dalam bentuk karbohidrat akan ditranslokasikan keseluruh jaringan tanaman dan selanjutnya akan digunakan untuk menunjang pertumbuhan dan perkembangan organ tanaman. Gardner, et al (1991) menambahkan bahwa Bobot kering total tanaman mencerminkan banyaknya asimilat yang dapat dihasilkan oleh tanaman. Hal ini mengindikasikan bahwa, apabila bobot kering total tanaman yang dihasilkan adalah rendah, maka asimilat yang dihasilkan juga rendah. Tujuan utama pengapuran adalah meningkatkan $\mathrm{pH}$, bukan untuk menambah unsur hara makro yang dibutuhkan tanaman; pengapuran lebih cenderung merubah sifat tanah menjadikan unsur hara lebih tersedia bagi tanaman. Begitu juga pupuk hayati tergantung kepada sifat kimia dan fisika tanah.

Jumlah Bintil Akar Efektif. Data pengamatan dan hasil analisis untuk jumlah bintil akar efektif yang diamati pada 6 MST (Tabel 1) tidak menunjukkan perbedaan dari semua pengaruh perlakuan yang diberikan. Tujuan pengapuran tanah di antaranya adalah selain untuk menaikkan $\mathrm{pH}$ tanah, menambah unsur $\mathrm{Ca}, \mathrm{Mg}$ dan juga membuat ketersediaan $\mathrm{P}$ maupun Mo, mengurangi keracunan $\mathrm{Fe}$, $\mathrm{Mn}$ dan $\mathrm{Al}$, memperbaiki kehidupan mikroorganisme tanah dan mengaktifkan pembentukan bintil-bintil akar (Sutanto, 2002). Bintil akar terbentuk akibat adanya asosiasi antara akar tanaman dengan mikroba penambat $\mathrm{N}$ (Rhizobium). Bintil akar berasal dari rambut akar tanaman yang terinfeksi oleh bakteri rhizobium dan mengalami perubahan bentuk. Jadi dalam satu bintil akar mengandung banyak bakteri rhizobium. Bakteri ini dapat hidup pada lingkungan oksigen $\left(\mathrm{O}_{2}\right)$ terbatas (anaerobik) maupun pada kondisi kaya oksigen (aerobik), namun lebih menyukai kondisi yang aerobik. Waktu yang dibutuhkan dari terjadinya infeksi hingga terbentuknya bintil akar kecil sekitar 7 hari. Kondisi $\mathrm{pH}$ tanah yang rendah atau terlalu tinggi juga menghambat perkembangan rhizobium (Taufiq dan titik, 2012).

Tabel 1. Pengaruh pupuk hayati dan pengapuran terhadap bobot kering, bintil akar efektif, jumlah cabang produktif dan indeks luas daun.

\begin{tabular}{cccccr}
\hline Perlakuan & $\begin{array}{c}\text { Tinggi } \\
\text { Tanaman }\end{array}$ & $\begin{array}{c}\text { Bobot Kering } \\
(\mathrm{g})\end{array}$ & $\begin{array}{c}\text { jumlah Bintil } \\
\text { Akar Efektif }\end{array}$ & $\begin{array}{c}\text { Cabang } \\
\text { Produktif }\end{array}$ & $\begin{array}{c}\text { Indeks Luas } \\
\text { Daun }\end{array}$ \\
\hline $\mathrm{A}$ & $9,6 \mathrm{a}$ & $31,76 \mathrm{a}$ & $12,30 \mathrm{a}$ & $2,93 \mathrm{ab}$ & $1,59 \mathrm{a}$ \\
$\mathrm{B}$ & $17 \mathrm{~b}$ & $27,30 \mathrm{a}$ & $18,30 \mathrm{a}$ & $2,60 \mathrm{ab}$ & $1,38 \mathrm{a}$ \\
$\mathrm{C}$ & $21,08 \mathrm{~b}$ & $39,43 \mathrm{a}$ & $12,00 \mathrm{a}$ & $2,26 \mathrm{a}$ & $1,82 \mathrm{a}$ \\
$\mathrm{D}$ & $19,83 \mathrm{~b}$ & $31,90 \mathrm{a}$ & $12,53 \mathrm{a}$ & $3,06 \mathrm{ab}$ & $2,07 \mathrm{a}$ \\
$\mathrm{E}$ & $19,16 \mathrm{~b}$ & $36,36 \mathrm{a}$ & $17,40 \mathrm{a}$ & $3,26 \mathrm{~b}$ & $2,00 \mathrm{a}$ \\
$\mathrm{F}$ & $19,5 \mathrm{~b}$ & $39,06 \mathrm{a}$ & $15,93 \mathrm{a}$ & $2,73 \mathrm{ab}$ & $2,13 \mathrm{a}$ \\
$\mathrm{G}$ & $20,58 \mathrm{~b}$ & $33,26 \mathrm{a}$ & $17,06 \mathrm{a}$ & $3,13 \mathrm{~b}$ & $1,57 \mathrm{a}$ \\
$\mathrm{H}$ & $20,16 \mathrm{~b}$ & $32,25 \mathrm{a}$ & $13,13 \mathrm{a}$ & $3,20 \mathrm{~b}$ & $2,17 \mathrm{a}$ \\
$\mathrm{I}$ & & $31,16 \mathrm{a}$ & $16,00 \mathrm{a}$ & $3,30 \mathrm{~b}$ & $1,91 \mathrm{a}$ \\
\hline
\end{tabular}

Keterangan: Angka-angka yang diikuti huruf yang sama tidak berbeda nyata menurut uji duncan taraf $5 \%$ 
Penambahan pupuk hayati dengan dosis yang tepat akan memperbaiki kesuburan biologi dan aerasi tanah, karena pupuk hayati dapat membantu memperbaiki sifat biologi dan fisika tanah.

Jumlah Cabang Produktif. Jumlah cabang produktif dihitung pada saat tanaman panen, pupuk hayati dan pengapuran cenderung berpengaruh pada dosis yang lebih tinggi (Tabel 1). Hasilnya tidak menunjukkan pengaruh yang nyata. Hal tersebut diduga sebagai faktor yang mempengaruhi jumlah cabang produktif pada tanaman kedelai pada saat pertumbuhan. Dengan penambahan kapur dan pupuk hayati, jumlah cabang diharapkan dapat meningkat karena sistem perakaran menjadi lebih baik untuk menyerap unsur hara, sehingga pertumbuhan cabang produktif lebih banyak (Tisdale, et al, 1993).

Indeks Luas Daun. Pengamatan Indeks luas daun dilakukan pada saat tanaman berumur 6 MST dengan mengambil 5 sampel tanaman dari masing-masing perlakuan (Tabel 1), tidak menunjukkan perbedaan karena tanaman telah memasuki fase generatif dan telah menghasilkan daun yang cukup banyak dan lebarnya atau terbukanya telah sempurna walaupun masih ada daun yang masih dalam tahap pertumbuhan, juga indeks luas daun dilakukan bersamaan dengan pengambilan dan penghitungan bintil akar.

Metode yang dilakukan untuk mengetahui indeks luas daun ini adalah metode Gravimetri. Pada indeks luas daun hasil yang terbaik terdapat pada perlakuan $\mathrm{H}$, dan hasil rata-rata dari setiap perlakuan berkisar antara 0,73-1,08. Sitompul dan Guritno (1995) menyatakan indeks luas daun pada kebanyakan tanaman dilapangan adalah nol untuk tanaman yang ditanam dengan biji dan selama beberapa minggu kemudian dapat kurang dari 1.0. Pupuk hayati dan pengapuran secara tidak langsung dapat meningkatkan jumlah daun karena kondisi perakaran dapat berkembang dengan baik ( Tisdale, et al, 1993).

Pengamatan Komponen Hasil. Pengamatan komponen hasil dalam percobaan ini terdiri dari jumlah polong per tanaman, polong isi per tanaman, jumlah biji per tanaman, bobot 100 biji, bobot biji per tanaman dan indeks panen. Hasil analisis dapat dilihat pada Tabel 2.

Jumlah Polong per Tanaman. Jumlah polong didapatkan setelah panen, data pengamatan dan hasil analisis statistik (Tabel 2). pada jumlah polong per tanaman tidak menunjukan hasil yang signifikan dengan ratarata polong berkisar antara $23,73-31,73$ polong.

Tabel 2. Pengaruh pupuk hayati dan pengapuran terhadap jumlah polong per tanaman dan persentase polong isi.

\begin{tabular}{ccc}
\hline Perlakuan & $\begin{array}{c}\text { Jumlah polong per } \\
\text { tanaman }\end{array}$ & $\begin{array}{c}\text { Persentase } \\
\text { polong isi }\end{array}$ \\
\hline A & $26,40 \mathrm{a}$ & $87,66 \mathrm{a}$ \\
B & $23,73 \mathrm{a}$ & $88,66 \mathrm{a}$ \\
C & $28,26 \mathrm{a}$ & $83,66 \mathrm{a}$ \\
D & $25,30 \mathrm{a}$ & $85,00 \mathrm{a}$ \\
E & $31,73 \mathrm{a}$ & $87,66 \mathrm{a}$ \\
F & $28,80 \mathrm{a}$ & $88,00 \mathrm{a}$ \\
G & $31,06 \mathrm{a}$ & $91,00 \mathrm{a}$ \\
H & $25,53 \mathrm{a}$ & $92,00 \mathrm{a}$ \\
I & $29,73 \mathrm{a}$ & $86,66 \mathrm{a}$ \\
\hline
\end{tabular}

Keterangan: Angka-angka yang diikuti huruf yang sama tidak berbeda nyata menurut uji Duncan taraf $5 \%$

Aplikasi legin (Rhizobium) mampu meningkatkan jumlah polong/tanaman; jumlah polong yang dihasilkan tanaman kedelai sangat ditentukan oleh pertumbuhan vegetatif dalam hal ini seperti laju fotosintesis dan pasokan hasil asimilasi. Jumlah polong yang terbentuk dipengaruhi oleh hara tertentu yang berperan dalam pembentukan bunga, hara mikro yang diserap tanaman untuk pertumbuhan reproduktif adalah $\mathrm{Bo}, \mathrm{Ca}, \mathrm{S}$ dan Mo. Unsur hara ini dimanfaatkan untuk pematangan biji, pembentukan protein dan menetralkan asamasam organik yang dihasilkan dalam metabolisme, bunga yang terbentuk akan mempengaruhi jumlah polong yang terbentuk, sehingga dapat mempengaruhi berat polong dan berat biji (Gardner, et al, 1991). Pengapuran dan pupuk hayati yang diberikan, dosisnya belum mampu mengkondisikan tanah agar tanaman mampu membentuk polong lebih banyak.

Persentase Polong Isi. Pengamatan dilakukan saat tanaman selesai dipanen, dengan menghitung jumlah polong yang ber isi pada masing-masing tanaman. Data pengamatan dan hasil analisis statistik pada polong isi per tanaman tidak memberikan pengaruh yang signifikan, rata-rata polong isi per tanaman berkisar antara 83,66 - 92 .

Pemberian pupuk tidak berpengaruh nyata terhadap jumlah polong isi dan biji per polong diduga karena jumlah polong yang terbentuk dan menghasilkan biji diantaranya dipengaruhi 
oleh keberhasilan persilangan, semakin tinggi keberhasilan persilangan maka semakin tinggi jumlah polong isi yang terbentuk. Dalam pengisian polong dan pembentukan biji sangat tergantung pada ketersediaan $\mathrm{N}$, baik $\mathrm{N}$ yang diambil oleh bakteri Rhizobium dari udara maupun $\mathrm{N}$ yang tersedia dalam tanah dan dipengaruhi juga oleh ketersediaan unsur $\mathrm{P}$ (Simanungkalit, 2006). Pengapuran dan pupuk hayati yang diberikan, dosisnya belum mampu mengkondisikan tanah agar tanaman mampu membentuk polong lebih banyak.

Bobot Biji per Tanaman. Bobot biji pertanaman didapatkan dari tanaman yang telah dipanen dan dipisahkan dari polongnya, lalu ditimbang dengan timbangan analitik, menunjukkan pengaruh yang tidak berbeda; bobot rata-rata biji pada setiap perlakuan berkisar antara 23,73 - 31,75 (Irwan, 2006). Data pengamatan dan hasil analisis statistik pada bobot biji per tanaman data dapat dilihat pada Tabel 3.

Bobot 100 biji dan Jumlah Biji per Polong. Pengamatan dilakukan dengan menimbang 100 butir biji kedelai dari masing-masing perlakuan dengan menggunakan timbangan analitik. Data pengamatan dan hasil analisis statistik pada bobot 100 biji. Bobot biji 100 butir tidak dapat memberikan pengaruh yang signifikan rata-rata bobot 100 butir dari setiap perlakuan berkisar antara 11,03 - 13,9 g. Lingga dan Marsono (2008) menjelaskan bahwa perkembangan biji lebih dipengaruhi oleh pasokan $\mathrm{N}$ selama pembentukan biji. Unsur $\mathrm{P}$ juga dibutuhkan untuk sintesa protein, $\mathrm{P}$ yang cukup pada pengisian biji akan memperbesar biji yang akan dihasilkan sehingga meningkatkan bobot 100 biji.

Pengamatan dilakukan setelah panen tidak memberikan hasil yang signifikan; rata-rata jumlah biji per polong berkisar antara 2,05 - 2,19 biji. Jumlah biji yang didapatkan dapat dipengaruhi oleh beberapa faktor seperti kurangnya serapan hara dalam pengisian polong sehingga bentuk biji tidak sempurna atau bahkan tidak terjadi pengisian biji, lalu adanya hama dan penyakit yang mengganggu dalam pengisian polong.

Indeks Panen. Indeks panen dapat diketahui pada setelah panen dan didapatkan dari hasil bobot biji dan bobot kering tanaman (berangkasan), dari hasil data indeks panen yang telah dianaliasis tidak memberikan pengaruh yang siginifikan, rata-rata dari setiap perlakuan berkisar antara $0,4-0,52$.

Data pengamatan dan hasil analisis statistik pada indeks panen disajikan pada Tabel 4 .

Indeks panen kedelai berpengaruh terhadap hasil biji kedelai. Genotipe yang mempunyai indeks panen tinggi berpotensi memberikan hasil biji yang tinggi. Indeks panen merupakan karakter penting yang turut menentukan hasil biji. Korelasi antara indeks panen dengan hasil biji lebih konsisten dibandingkan dengan karakter lainnya, karena pengaruh lingkungan terhadap indeks panen relatif sangat kecil (Hilman, 2005).

Perlakuan pengapuran dan pupuk hayati tidak secara langsung berpengaruh terhadap hasil. Hal ini disebabkan karena keduanya tidak langsung bersifat menyediakan unsur hara makro dan mikro secara lengkap untuk kebutuhan tanaman legum, namun bersifat mengkondisikan keadaan sifat fisika agar lebih baik sehingga pertumbuhan akar menjadi lebih baik, dan sifat biologi tanah agar jasad renik di dalam tanah menjadi lebih berkembang dengan baik dan dapat bersinergi dengan akar tanaman legum.

Tabel 3. Pengaruh pupuk hayati dan pengapuran terhadap bobot 100 butir, jumlah biji per polong dan bobot biji per tanaman (hasil/ha).

\begin{tabular}{cccccc}
\hline Perlakuan & $\begin{array}{c}\text { Bobot 100 Butir } \\
(\mathrm{g})\end{array}$ & $\begin{array}{c}\text { Bobot 100 Butir } \\
(\mathrm{g})\end{array}$ & $\begin{array}{c}\text { Jumlah Biji Per } \\
\text { Polong (butir) }\end{array}$ & $\begin{array}{c}\text { Bobot Biji Per } \\
\text { Tanaman }(\mathrm{g})\end{array}$ & $\begin{array}{c}\text { Hasil per ha } \\
\text { (ton/ha) }\end{array}$ \\
\hline $\mathrm{A}$ & $13,63 \mathrm{a}$ & $13,63 \mathrm{a}$ & $2,11 \mathrm{a}$ & $31,20 \mathrm{a}$ & 0.936 \\
$\mathrm{~B}$ & $11,53 \mathrm{a}$ & $11,53 \mathrm{a}$ & $2,19 \mathrm{a}$ & $25,60 \mathrm{a}$ & 0.768 \\
$\mathrm{C}$ & $11,03 \mathrm{a}$ & $11,03 \mathrm{a}$ & $2,10 \mathrm{a}$ & $30,46 \mathrm{a}$ & 0.914 \\
$\mathrm{D}$ & $13,06 \mathrm{a}$ & $13,06 \mathrm{a}$ & $2,11 \mathrm{a}$ & $25,76 \mathrm{a}$ & 0.773 \\
$\mathrm{E}$ & $13,90 \mathrm{a}$ & $13,90 \mathrm{a}$ & $2,10 \mathrm{a}$ & $36,50 \mathrm{a}$ & 1.095 \\
F & $12,93 \mathrm{a}$ & $12,93 \mathrm{a}$ & $2,05 \mathrm{a}$ & $36,86 \mathrm{a}$ & 1.106 \\
G & $13,26 \mathrm{a}$ & $13,26 \mathrm{a}$ & $2,10 \mathrm{a}$ & $36,40 \mathrm{a}$ & 1.092 \\
H & $12,66 \mathrm{a}$ & $12,66 \mathrm{a}$ & $2,11 \mathrm{a}$ & $31,33 \mathrm{a}$ & 0.939 \\
I & $13,90 \mathrm{a}$ & $13,90 \mathrm{a}$ & $2,08 \mathrm{a}$ & $33,06 \mathrm{a}$ & 0.991 \\
\hline
\end{tabular}

Keterangan: Angka-angka yang diikuti huruf yang sama tidak berbeda nyata menurut uji duncan taraf $5 \%$ 
Tabel 4. Pengaruh pupuk hayati dan pengapuran terhadap indeks panen.

\begin{tabular}{cc}
\hline Perlakuan & Indeks Panen \\
\hline A & $0,49 \mathrm{a}$ \\
B & $0,47 \mathrm{a}$ \\
C & $0,40 \mathrm{a}$ \\
D & $0,45 \mathrm{a}$ \\
E & $0,48 \mathrm{a}$ \\
F & $0,43 \mathrm{a}$ \\
G & $0,52 \mathrm{a}$ \\
H & $0,47 \mathrm{a}$ \\
I & $0,50 \mathrm{a}$ \\
\hline
\end{tabular}

Keterangan: Angka-angka yang diikuti huruf yang tidak berbeda nyata menurut uji duncan taraf 5\%

\section{Kesimpulan dan Saran}

Kesimpulan. Aplikasi pupuk hayati dan pengapuran tidak menunjukkan berpengaruh nyata pada beberapa parameter pengukuran yang diamati, seperti jumlah daun, jumlah polong, jumlah biji, jumlah bunga, bobot kering tanaman, bintil akar efektif, Indeks Luas Daun (ILD), bobot biji, Indeks Panen dan bobot 100 butir, namun berpengaruh nyata pada pengamatan tinggi tanaman 3 MST, 4 MST dan 5 MST serta jumlah cabang produktif.

\section{Saran :}

1. Perlu dilakukan penelitan lebih lanjut dalam penggunaan pengapuran dengan waktu aplikasi yang berbeda.

2. Dosis pupuk hayati disarankan untuk ditingkatkan lagi, karena tanaman kedelai cukup responsif terhadap keberadaan jasad renik.

\section{Ucapan Terima Kasih}

1. Mahasiswa Minat Pangan Fakultas Pertanian Universitas Padjadjaran.

2. Kepala Kebun Ciparanje Fakultas Pertanian Universitas Padjadjaran Bandung.

\section{Daftar Pustaka}

Atman, 2006. Pengelolaan Tanaman Kedelai di Lahan Kering Masam. Sumatera Barat. Balai Pengkaji Teknologi Pertanian. Jurnal Ilmiah Tambua, Vol. V, No. 3, 281-287. ISSN 1412-5838

Gardner FP, Pearce RB, Mitchell RL (1991) Physiology of crop plants. Diterjemahkan oleh H. Susilo. Universitas Indonesia Press, Jakarta.

Hanum, C., W. Q. Mugnisjah, S. Yahya, D. Sopandy, K. Idris, dan A. Sahar. 2007. Pertumbuhan Akar Kedelai pada Cekaman Alumunium, Kekeringan dan Cekaman Ganda. Agritrop, 26 (1) : 13-18.

Hilman, Y. 2005. Teknologi produksi kedelai di lahan kering masam. Dalam Makarim, et al. (penyunting). Prosiding Lokakarya Pengembangan Kedelai di Lahan Suboptimal. Puslitbangtan Bogor, 2005; 78-86 hlm

Irwan, Aep Wawan. 2006. Budidaya Tanaman Kedelai (Glycine max (L.) Merill). Universitas Padjajaran: Jatinangor.

Salisbury F B dan Ross C W. 1995. Fisiologi Tumbuhan. Lukman dan Sumaryono, penerjemah. Bandung (ID) : ITB Press. Terjemahan dari : Plant physiology.

Simanungkalit, R.D.M. 2006. Prospek Pupuk Organik dan Pupuk Hayati di Indonesia.

Sitompul, S. M. dan B. Guritno. 1995. Analisis Pertumbuhan Tanaman. Gadjah Mada University Press. Yogyakarta. $412 \mathrm{Hlm}$.

Taufiq, Abdullah dan Titik Sundari. 2012. Respons Tanaman Kedelai Terhadap Lingkungan Tumbuh. Buletin Palawija No. 23: 13-26

Tisdale, Samuel L., Warner L. Nelson, James D. Beaton and John L. Havlin. 1993. Soil Fertillity and Fertilizers. MacMillan Publ. Co. Canada Toronto. Fifth Ed. p. 45-79. 